\title{
Pelatihan Konselor Teman Sebaya Dalam Upaya Peningkatan Gizi Dan Reproduksi Pada Remaja
}

\author{
Dhian Luluh Rohmawati*, Nurul Hidayah, Marwan \\ Akademi Keperawatan Pemerintah Kabupaten Ngawi, Indonesia \\ * dhian.luluh@gmail.com
}

\begin{abstract}
ABSTRAK
Masa remaja merupakan masa yang mengalami pertumbuhan dan perkembangan yang sangat pesat yang menyebabkan terjadinya perubahan fisik dan psikologis yang cepat. Perubahan ini akan menyebabkan permasalahan dan perubahan perilaku. Pengabdian masyarakat ini bertujuan untuk membentuk konselor teman sebaya yang nantinya diharapkan dapat membantu memecahkan masalah remaja khususnya tentang gizi dan kesehatan reproduksi pada Remaja di Dusun Cung Belut Desa Semen Kecamatan Paron Kabupaten Ngawi. Pengabdian masyarakat ini terdiri dari 2 kegiatan utama, yaitu penyuluhan dan pelatihan konselor teman sebaya. Hasilnya adalah adanya peningkatan kemampuan dan pemahaman remaja dalam permasalahan remaja serta terbentuknya 20 konselor teman sebaya. Dengan dibentuknya konselor teman sebaya ini diharapkan menjadi solusi permasalahan yang terjadi pada remaja, khususnya pada bidang kesehatan.
\end{abstract}

Kata Kunci: Gizi, Kesehatan Reproduksi, Konselor Teman Sebaya, Remaja

Received: June 28, 2020

Revised: July 18,2020

Accepted: August 18, 2020

This is an open-acces article distributed under the terms of the Creative Commons Attribution-ShareAlike 4.0 International License.

\section{PENDAHULUAN}

Masa remaja merupakan periode dengan rentang usia berkisar 10 sampai 24 tahun yang mengalami pertumbuhan dan perkembangan yang terjadi secara dinamis dan pesat baik fisik, psikologis, intelektual, sosial. Periode ini juga merupakan peralihan dari masa kanak-kanak menuju masa dewasa dan normal terjadi pada kehidupan manusia yang akan berdampak pada perubahan fisik dan psikologis yang cepat (Marcell, et. al., 2011). Perubahan fisik yang dapat terjadi pada remaja dapat dilihat dari pertumbuhan badan yang pesat dan matangnya organ reproduksi. Perubahan yang terjadi pada remaja cenderung akan menyebabkan beberapa permasalahan dan perubahan perilaku kehidupan remaja.

Prevalensi jumlah populasi remaja dengan usia 10-19 tahun sebanyak 1,2 milyar atau 16\% dari populasi dunia (UNICEF, 2016). Populasi remaja dengan usia 10-24 tahun di ASIA sebanyak 802 juta pada tahun 2013. Data jumlah remaja usia 15-24 tahun di Indonesia berdasarkan hasil survei Penduduk Antar Sensus pada tahun 2015 mencapai 42.061,2 juta atau sebesar 16,5\% dari total penduduk Indonesia. Jumlah popolasi remaja di Jawa Timur menurut data BPS (2017) adalah sebesar 9.134.061 jiwa atau sebesar 23,25 $\%$ dari total penduduk JawaTimur. 


\section{Journal of Community Engagement in Health}

Remaja dalam tahap perkembangannya memerlukan perhatian orang lain. Dalam tahap perkembangan terutama aspek sosial, remaja lebih melibatkan kelompok teman sebaya dibandingkan dengan orang tua (Conger (1991); Papalia \& Olds (2001) dalam Hidayati, Lukman, Sriati, Widianti, Agustina (2017). Remaja dalam menghadapi permasalahannya memerlukan perhatian penuh teman sebayanya. Hal ini dikarenakan remaja sering melakukan kegiatan di luar rumah seperti kegiatan ekstrakurikuler, karang taruna, kegiatan sekolah, dan kegiatan bermain dibandingkan pada usia kanak-kanak. Hal ini menyebabkan pada masa remaja yang mempunyai peran terhadap dirinya adalah peran kelompok teman sebaya (Hidayati, Lukman, Sriati, Widianti, Agustina (2017).

Beberapa penelitian sudah membuktikan bahwa adanya kelompok teman sebaya dapat membantu permasalahan yang terjadi pada remaja. Penelitian yang dilakukan oleh Shohib (2016) menunjukkan hasil bahwa adanya pembentukan kelompok teman sebaya di sekolah dapat membantu penanganan permasalahan pada remaja. Selain itu juga penelitian Harini, dkk (2014) yang menyimpulkan bahwa terdapat pengaruh yang signifikan pada pelatihan konselor teman sebaya terhadap pengetahuan, sikap, dan keterampilan.

Perubahan perilaku pada segi fisik yang dapat terjadi pada masa remaja adalah adanya perubahan perilaku makan baik mengarah pada perilaku makanan yang sehat maupun cenderung mengarah kepada perilaku makan yang tidak sehat (Proverawati, 2010). Jika seseorang mempunyai perilaku makan yang baik maka kebutuhan gizi akan cukup untuk hidup sehat dan produktif. Namun jika seorang remaja mempunyai perilaku makan yang tidak baik seperti makan tidak teratur baik waktu ataupun jenis makanan, diet penurunan berat badan, binge eating, kebiasaan makan pada malam hari dapat merusak kesehatan dan kesejahteraan psikologis seseorang (Pujiwati, Arneliwati, Rahmalia, 2015).

Apabila remaja mengalami kerusakan pada kesejahteraan psikologis maka akan berdampak pada perilaku psikologis mereka. Masa remaja ini seseorang memiliki rasa keingintahuan yang besar, suka terhadap tantangan serta cenderung berani mengambil risiko tanpa pertimbangan yang matang (Soetjiningsih, 2004). Apabila masa remaja tidak mendapat lingkungan yang baik maka seseorang akan mudah melakukan perilaku yang menyimpang. Jika hal ini tidak dilakukan upaya pencegahan sedini mungkin maka akan menyebabkan banyak remaja yang terjerumus pada pergaulan bebas.

Menurut Hastutik (2012) mengatakan bahwa angka pernikahan dini pada usia $<16$ tahun sebanyak 10\%. Berdasarkan penelitian diberbagai kota besar di Indonesia, sekitar 20-30\% remaja mengaku pernah melakukan hubungan seks. Kelompok remaja yang masuk dalam penelitian pernikahan dini tersebut rata-rata berusia 17-21 tahun dan umumnya masih bersekolah SLTA atau mahasiswa. Namun pada beberapa kasus juga terjadi pada anak yang duduk di tingkat SLTP. Menurut survei Komnas Perlindungan Anak di 33 Provinsi 2008, 97\% remaja SMP dan SMA pernak menonton film porno, 93,7\% remaja SMP dan SMA pernah ciuman, genetalia stimulation (meraba alat kelamin) dan oral seks (seks melalui mulut), 62,7\% remaja SMP dan SMA tidak perawan dan 21,2\% remaja mengaku pernah aborsi (BKKBN, 2010).

Berdasarkan studi pendahuluan yang dilakukan di Dusun Cung Belut Desa Semen Kecamatan Paron Kabupaten Ngawi menunjukkan bahwa remaja sebanyak 68 jiwa dari total keseluruhan penduduk. Dari hasil survei diperoleh data bahwa remaja sering melakukan aktivitas bersama seperti mengikuti karang taruna dan bermain bersama dengan teman sebaya. Selain itu didapatkan hasil bahwa $50 \%$ dari populasi remaja mengalami putus sekolah dan memilih untuk menikah dini dan ada juga yang merantau. Kurangnya informasi pendidikan ini akan berdampak pada kesehatan remaja sehingga akan meningkatkan perilaku menyimpang dikalangan remaja. 


\section{Journal of Community Engagement in Health}

Salah satu upaya yang dapat dilakukan untuk mencegah berkembangnya pergaulan bebas dikalangan masyarakat adalah dengan melakukan edukasi mengenai kesehatan reproduksi dan nutrisi pada remaja melalui bimbingan teman sebaya. Peran teman sebaya ini diharapkan akan membantu secara maksimal masalah yang sedang dihadapi oleh remaja khususnya pada masalah kesehatan. Salah satu cara yang dapat dilakukan untuk mengatasi masalah pada remaja yaitu dilakukan pelatihan konselor teman sebaya khususnya pada masalah gizi dan kesehatan reproduksi pada remaja.

\section{BAHAN DAN METODE}

Kegiatan Pengabdian kepada Masyarakat yang dilakukan oleh tim dosen dari Akademi Keperawatan Pemerintah Kabupaten Ngawi merupakan salah satu upaya untuk meningkatkan pengetahuan, sikap, dan keterampilan tentang Kesehatan Reproduksi dan gizi pada Remaja di Dusun Cung Belut Desa Semen Kecamatan Paron Kabupaten Ngawi. Kegiatan ini juga menjadi bagian dari upaya melaksanakan Tri Dharma Perguruan Tinggi.

Populasi dalam PKM ini adalah semua remaja yang tinggal di Dusun Cung Belut Desa Semen Kecamatan Paron Kabupaten Ngawi dengan total sasaran adalah sebanyak 68 remaja. Rangkaian kegiatan ini dilakukan selama 1 bulan di Dusun Cung Belut Desa Semen Kecamatan Paron Kabupaten Ngawi. Dalam pelaksanaannya, kegiatan ini telah dilakukan dengan metode pendekatan sebagai berikut: ceramah dengan melakukan pemaparan materi secara langsung, dengan bantuan visualisasi menggunakan power point dan video singkat. Metode ini digunakan untuk memberi wawasan mendalam kepada peserta mengenai pentingnya gizi seimbang dan kesehatan reproduksi pada remaja. Selain itu juga diberikan materi tentang tata cara menjadi konselor teman sebaya. Kemudian setelah pemaparan materi dilaksanakan, kami juga melakukan diskusi interaktif. Pada hari selanjutnya kami melakukan pelatihan konselor teman sebaya, dimana masing-masing peserta diminta untuk mempraktikkan menjadi seorang konselor. Kegiatan ini dilakukan secara berkelompok. Masing-masing peserta mendapat bagian menjadi konselor dan konseli. Instrumen yang digunakan dalam kegiatan pengabdian masyarakat ini adalah sound system, LCD, dan leaflet.

\section{HASIL DAN PEMBAHASAN}

Kegiatan ini dilakukan di Dusun Cung Belut Desa Semen Kecamatan Paron Kabupaten Ngawi dengan jumlah remaja yang hadir adalah sebanyak 68 orang, yang aktif datang dalam kegiatan penyuluhan dan pelatihan sejumlah 60 remaja. Adapun data peserta yang hadir adalah 48 remaja berjenis kelamin perempuan dan 12 remaja berjenis kelamin laki-laki. Tingkat pendidikan yang sedang ditempuh adalah 43,33 \% SMP, 56,67 SMA. Semua remaja mengalami gizi rendah sebesar $11,7 \%$, gizi seimbang sebesar 56,67\%, gizi berlebih sebesar 31,67\%. Kegiatan penyuluhan kesehatan dilakukan sebanyak 2 kali dan dengan waktu 120 menit. Kegiatan penyuluhan yang dilakukan adalah pendidikan kesehatan mengenai gizi seimbang dan kesehatan reproduksi. Selanjutnya kami melakukan pelatihan konselor teman sebaya. Pelaksanaan penyuluhan dan pelatihan konselor teman sebaya dilakukan yang dibagi menjadi tiga tahap, yaitu:

\section{Tahap Persiapan}

Tahap persiapan ini dilakukan penyebaran undangan dengan melibatkan mahasiswa, yang diberikan pada remaja dusun semen tentang kegiatan pelatihan konselor teman sebaya untuk meningkatkan gizi dan reproduksi remaja. Remaja yang diundang sejumlah 68 orang. Selain itu juga melakukan persiapan sarana prasarana yang meliputi persiapan tempat, persiapan bahan pendukung kegiatan seperti LCD, layar proyektor, materi penyuluhan, leaflet, dan sound sistem. 


\section{Tahap Pelaksanaan}

\section{1) Penyuluhan Gizi Remaja}

Kegiatan ini bertujuan untuk meningkatkan pemahaman remaja mengenai status gizi yang tepat pada usia remaja. Pelaksanaan kegiatan pengabdian masyarakat oleh dosen Akper Pemkab Ngawi yang dilakukan di Dusun Cung Belut Desa Semen Kecamatan Paron wilayah kerja Puskesmas Teguhan, meliputi tiga tahapan yaitu: kegiatan di awali dengan pemeriksaan kesehatan pada remaja yang meliputi pengukuran tinggi badan, berat badan serta IMT. Setelah pemeriksaan kesehatan selesai, remaja diberikan penyuluhan terkait dengan gizi yang tepat pada usia remaja dan bahaya jika gizi kurang dan berlebih. Pelatihan ini dihadiri oleh 60 remaja, tim pengabdian masarakat Akper Pemkab Ngawi,dan Mahasiswa sebagai enumerator. Hari berikutnya adalah pembentukan kelompok teman sebaya. Setiap kelompok akan didampingi oleh tim pengabdian masyarakat dan mahasiswa. Antusiasme remaja saat dilaksanakan penyuluhan juga tinggi, hal ini dilihat dari banyaknya pertanyaan yang diungkapkan saat penyuluhan berlangsung. Pada pelaksanaan kegiatan ini kami menggunakan metode ceramah, diskusi dan pemutaran video, tentang gizi yang seimbang pada usia remaja. Evaluasi dari kegiatan ini adalah peningkatan pemahaman remaja tentang manfaat gizi seimbang, yang dibuktikan dengan warga dapat menyebutkan kembali manfaat dari gizi seimbang pada usia remaja.

\section{2) Penyuluhan Kesehatan Reproduksi Remaja}

Tujuan dari kegiatan ini adalah untuk meningkatkan pemahaman remaja mengenai pentingnya menjaga kesehatan pada usia remaja. Pelatihan ini dihadiri oleh 60 remaja, tim pengabdian masarakat Akper Pemkab Ngawi,dan Mahasiswa sebagai enumerator. Setiap kelompok akan didampingi oleh tim pengabdian masyarakat dan mahasiswa. Antusiasme remaja saat dilaksanakan penyuluhan juga tinggi, hal ini dilihat dari banyaknya pertanyaan yang diungkapkan saat penyuluhan berlangsung. Pada pelaksanaan kegiatan ini kami menggunakan metode ceramah, diskusi dan pemutaran video, tentang kesehatan reproduksi pada remaja. Evaluasi dari kegiatan ini adalah remaja mengalami peningkatan pemahaman remaja tentang kesehatan reproduksi remaja, yang dibuktikan dengan remaja dapat menyebutkan kembali manfaat dari menjaga kesehatan reporduksi remaja.

\section{3) Pelatihan Konselor Teman Sebaya}

Pelatihan konselor teman sebaya ini dilaksanakan pada tanggal 11 Maret 2019. Adapun tujuan dari kegiatan ini adalah untuk meningkatkan pemahaman remaja mengenai pentingnya memberikan edukasi kepada teman sebaya sehingga dapat meningkatkan status gizi dan kesehatan reproduksi pada remaja. Metode yang digunakan adalah metode ceramah, diskusi, dan simulasi. Kegiatan ini juga dihadiri oleh 60 remaja. Setelah mengikuti pelatihan yang aktif menjadi konselor sebanyak 20 remaja. Diakhir kegiatan pelatihan ini diberikan sertifikat dan pemasangan PIN sebagai tanda bahwa peserta sekarang adalah sebagai konselor teman sebaya dilingkungan Dusun Cung Belut Desa Semen Kecamatan Paron wilayah kerja Puskesmas Teguhan. 


\section{Journal of Community Engagement in Health}

\section{Evaluasi}

Semua sarana dan prasarana yang digunakan dalam kegiatan pengabdian masyarakat di dusun cung belut telah di siapkan sebelum kegiatan dimulai. Dosen bersama Mahasiswa Akper Pemkab Ngawi yang saling bantu membantu demi tercapainya kegiatan secara maksimal. Jumlah remaja yang hadir dalam kegiatan ini sejumlah 60 orang dari total lansia 68 orang di dusun balongcapang. Ketidakhadiran remaja ini disebabkan karena ada remaja yang tidak tinggal di daerah tersebut.

Evaluasi dari pelatihan teman sebaya yang telah terbentuk dapat melakukan dan mempraktikkan kemampuan mereka dalam melakukan konseling terhadap teman mereka di lingkungan rumah. Secara keseluruhan dari kegiatan pengabdian masyarakat yang dilakukan di Dusun Cung Belut Desa Semen Kecamatan Paron Kabupaten Ngawi, mulai dari penyuluhan gizi dan reproduksi remaja dan pelatihan konselor teman sebaya berlangsung dengan tertib dan lancar.

\section{KESIMPULAN}

Penyuluhan dan pelatihan yang dilakukan di Dusun Cung Belut Desa Semen Kecamatan Paron Kabupaten Ngawi dapat diselenggarakan dengan baik dan berjalan lancar sesuai rencana yang telah disusun. Antusiasme peserta sangat tinggi terbukti dari banyak peserta yang aktif bertanya sehingga dapat dikatakan bahwa pelatihan ini dapat dipahami dengan baik oleh peserta.

\section{REFERENSI}

Alwi, H. (2007). Kamus Besar Bahasa Indonesia. Jakarta: Balai Pustaka

BPS Provinsi Jawa Timur. https://jatim.bps.go.id/dynamictable/2017/09/05/61/jumlahpenduduk-menurut-kelompok-umur-dan-jenis-kelamin-di-provinsi-jawa-timur2016.html. Diakses pada tanggal 3 Maret 2019 pukul 12.30.

Dedeh, dkk. (2010). Sehat Dan Bugar Berkat Gizi Seimbang. Jakarta: PT Penerbit Sarana Bobo.

Departemen Gizi dan Kesehatan Masyarakat FKM UI. (2007). Gizi Dan Kesehatan Masyarakat. Jakarta: PT Raja Grafindo Persada.

Harini, R., Rahmat, I., Nisman, W.A. 2014. Upaya Peningkatan Keterampilan Konseling Kesehatan Reproduksi Mahasiswa Melalui Pelatihan Konselor teman sebaya. Jurnal Ners. Vol 9 No.2 173:182.

Hidayati, N.O., Lukman, M., Sriati, A., Widianti, E., Agustina, H.S. (2017). Pembentukan Konselor Teman Sebaya dalam Upaya Preventif Perilaku Kekerasan Pada Remaja di Smp Negeri 1 Pangandaran. Dharmakarya: Jurnal Aplikasi Ipteks untuk Masyarakat; 6(2):125-128.

Imron. (2012). Pendidikan Kesehatan Reproduksi Remaja. Yogyakarta: Ar-Ruzz Media.

Kementerian kesehatan RI. (2015). INFODATIN Pusat Data dan Informasi Kementerian Kesehatan RI Situasi Kesehatan Remaja. 


\section{Journal of Community Engagement in Health}

http://jceh.org

ISSN: 2620-3758 (print); 2620-3766 (online)

https://doi.org/10.30994/jceh.v3i2.46

Vol.3 No.2. Sep 2020. Page.194-199

Kusmirah, E. (2011). Kesehatan Reproduksi Remaja dan Wanita. Jakarta : Salemba Medika

Marcell, A.V., Wibbelsman, C., Seigel, W.M. (2011). Male Adolescent Sexual and Reproductive Health Care. Pediatrics; 128: 1658-1678

Proverawati, A. (2010). Obesitas dan Gangguan Perilaku Pada Remaja (Cet.1). Yogyakarta: Nuha Medika.

Pujiati, Arneliwati, Rahmalia, S. (2015). Hubungan antara perilaku makan dengan status gizi pada remaja putri. JOM; 2 (2)

Sarwono, S.W.(2002). Psikologi Sosial. Jakarta: Balai Pustaka.

Santock, J.W. (2002). Life Span Development-Perkembangan Masa Hidup, (Alih Bahasa Achmad Chusairi dan Juda Damanik). Jakarta: Erlangga.

Shohib, M., Firmanto, A., Kusuma, W.A., Martasari, I.G. 2016. Pendampingan kelompok konselor teman sebaya di kota batu. Jurnal Dedikasi. Vol. 13 p 34-38. ISSN 16933214

Soetjiningsih. (2004). Buku Ajar: Tumbuh Kembang Remaja dan Permasalahannya. Jakarta : Sagung Seto.

Suwarjo. (2008). Konseling Teman Sebaya (Peer Counseling) untuk Mengembangkan Resiliensi Remaja. Makalah FIP UNY. 29 Februari 2008

UNICEF. (2016). Laporan Tahunan Indonesia 2016. -:-

UU Kesehatan No. 36 Tahun 2009 PP No. 61 Tahun 2014 Tentang Kesehatan Reproduksi

Yusuf, S. (2011). Psikologi Perkembangan Anak Dan Remaja. Bandung: PT. Remaja Rosdakarya. 